\title{
Ritual Nyadran Dam Bagong sebagai Wujud Pelestarian Budaya Lokal dan Sumber Belajar IPS SD Kelas IV
}

\author{
Siti Zullaikah Multina Putri ${ }^{1}$, Budi Eko Soetjipto ${ }^{2}$, Ery Tri Djatmika ${ }^{2}$ \\ ${ }^{1}$ Pendidikan Dasar-Universitas Negeri Malang \\ ${ }^{2}$ Manajemen-Universitas Negeri Malang
}

\section{INFO ARTIKEL}

\section{Riwayat Artikel:}

Diterima: 04-02-2020

Disetujui: 21-09-2020

\section{Kata kunci:}

the Nyadran Dam Bagong ritual; local culture;

elementary school students; ritual Nyadran Dam Bagong; budaya lokal;

siswa sekolah dasar

\author{
Alamat Korespondensi: \\ Siti Zullaikah Multina Putri \\ Pendidikan Dasar \\ Universitas Negeri Malang \\ Jalan Semarang 5 Malang \\ E-mail: sitizullaikah95@gmail.com
}

\begin{abstract}
The Dam Bagong traditional ritual or better known as the Nyadran tradition at Dam Bagong. The traditional ceremony is one part of the customs that exist in the community, namely the form of the implementation of traditional ceremonies in which there is a high cultural value and a lot of inspiration for the cultural wealth of the region that can add to the diversity of national culture. (I) Describe the Meaning of the implementation of the Bagad Dam Nyadran Ritual, Trenggalek Regency; (II) analysis of the Bagad Nyadran Dam Ritual values as a form of preservation of the Trenggalek local culture; (III) analysis of the values available in the Nyadran Dam Bagong tradition which can be used as a cultural preservation of Trenggalek. The approach used in this study is the ethnographic approach. The location of this research is located in Trenggalek Regency, East Java Province. The location of Bagong Dam is located in the village of Trenggalek. Then on the evening of the first Suro an art event is held as a form of celebration of joy and entertainment for the surrounding community and visitors, usually a shadow puppet show and jaranan dance or turonggoyakso dance next to the tomb of the Adipati Minak Sopal and witnessed by the Trenggalek community and residents outside Trenggalek.
\end{abstract}

ABSTRAK

\begin{abstract}
Abstrak: Ritual adat Dam Bagong atau lebih dikenal dengan Tradisi Nyadran di Dam Bagong. Upacara adat merupakan salah satu bagian dari adat istiadat yang ada pada masyarakat yaitu wujud pelaksanaan upacara adat yang didalamnya terdapat nilai budaya yang tinggi dan banyak inspirasi bagi kekayaan budaya daerah yang dapat menambah keanekaragaman budaya nasional. (I) Mendeskripsikan makna pelaksanaan ritual Bendungan Bagad Nyadran kabupaten Trenggalek; (II) analisis nilai ritual Bendungan Bagad Nyadran sebagai bentuk pelestarian budaya lokal Trenggalek; (III) analisis nilai-nilai yang tersedia di tradisi Nyadran Dam Bagong yang dapat digunakan sebagai pelestarian budaya Trenggalek. Pendekatan yang digunakan dalam penelitian ini adalah pendekatan etnografi. Lokasi penelitian ini terletak di Kabupaten Trenggalek Provinsi Jawa Timur. Lokasi Bendungan Bagong terletak di desa Trenggalek. Kemudian pada malam Suro pertama diadakan acara kesenian sebagai bentuk perayaan keceriaan dan hiburan bagi masyarakat sekitar dan pengunjung, biasanya pertunjukan wayang kulit dan tari jaranan atau tari turonggoyakso di samping makam Adipati Minak Sopal dan disaksikan oleh masyarakat Trenggalek dan warga luar Trenggalek.
\end{abstract}

Negara Indonesia merupakan negara yang kaya akan keanekaragaman baik dari segi budaya, adat istiadat, suku, agama, dan golongan. Setiap daerah mempunyai budaya dan tradisi yang berbeda dengan daerah lainnya. Secara tradisi, masyarakat terus berpegang pada nilai-nilai lokal yang diyakini kebenaran dan kesakralan serta menjadi pegangan hidup anggota masyarakat yang diwarisiskan secara turun menurun (Iswanto, 2018). Upacara tradisional merupakan salah satu bentuk kebudayaan dari hasil kegiatan dan penciptaan batin manusia seperti kepercayaan, kesenian dan adat istiadat yang dilaksanakan oleh warga yang bertujuan untuk selalu dilaksanakan secara turun menurun dan tidak pernah ditinggalkan hingga saat ini. Dalam kegiatan pembelajaran kurikulum 2013 mengaitkan beberapa tema-tema serta beberapa mata pelajaran lain (Makhmudah, 2017). Upacara tradisi dilakukan karena masyarakat beranggapan bahwa upacara ini merupakan kebiasaan yang diwariskan dari satu generasi ke generasi berikutnya secara turun menurun. 
Tradisi Nyadran Dam Bagong berawal dari kisah Adipati Minak Sopal yang berjuang untuk membangun sebuah Dam Bagong di kabupaten Trenggalek tepatnya di kelurahan Ngatru. Ritual upacara Nyadran Dam Bagong diawali dengan tahlilan disamping makam Adipati Minak Sopal dan dilanjutkan dengan ziarah ke makam Adipati Minak Sopal yang diikuti oleh para pejabat daerah dan masyarakat Trenggalek. Sementara itu, di halaman sekitar kompleks pemakaman disajikan hiburan jaranan tarian kepahlawanan khas Trenggalek yang diiringi gamelan yang dinamis dan menghentak (Zulia \& Yanuwiadi, 2015). Ringkasan acara Nyadran Dam Bagong ditutup dengan pagelaran wayang kulit dengan penyelenggaraan upacara yang serba lengkap menurut tradisi akan memberikan kemantapan batin kepada pelakunnya dalam mengagungkan berkat, rahmat dan perlindungan. Tradisi Nyadran sangatlah berpengaruh sehingga wajar apabila melahirkan kebersamaan dan pola tingkah laku dalam masyarakat yang bersangkutan (Rufaidah \& Sayekti, 2018). Suatu ringkaian peristiwa adat dan gotong royong adalah sekumpulan orang yang berja dan sukarela untuk menyelesaikan suatu pekerjaan yang mereka anggap keragaman budaya lokal. Salah satu cara mengapresiasi keragaman budaya lokal yaitu dengan pengintegrasian kearifan lokal tentang tradisi Nyadran Dam Bagong di Trenggalek (Dewi, Poedjiastoeti, \& Prahani, 2017).

Hasil wawancara pada saat penelitian tanggal 12-13 September 2019 bersama Bapak Naim seorang juru kunci Dam Bagong diperoleh hasil mengenai sejarah serta berdirinya Dam Bagong. Selain mewawancarai bapak Naim, peneliti juga mendapat buku tentang asal usul Dam Bagong dari dinas pariwisata. Berbekal buku dari dinas pariwisata, peneliti mengembangkan sebuah buku teks untuk mengenalkan kepada siswa tetang sejarah Dam Bagong. Peneliti melakukan penelitian kepada siswa kelas IV dimana di dalam buku bahasa jawa kelas IV terdapat cerita Dam Bagong yang sering dilakukan di kelurahan Ngatru dan peneliti bertanya kepada kepala sekolah di SDN 1 Ngatru pernah mempunyai buku tentang sejarah Dam Bagong ini dan buku itu hilang dan siswa sering menerapkan budaya bersih desa dan setiap bulan Suro tanggalan jawa, siswa yang sekolah tidak jauh dari Dam Bagong diliburkan agar dapat mengikuti acara prosesi lerung kepala kerbau dan di dalam prosesi tersebut siswa diberi tugas membuat cerita dalam bentuk cerita dan dibaca ucap kepala sekolah SDN 1 Ngatru Trenggalek.

Hasil pengamatan saat observasi proses pembelajaran di kelas IV pada tanggal 1 Juli 2019 di SDN 1 Ngatru Trenggalek, diperoleh informasi bahwa bahan ajar berpedoman pada buku pemerintah edisi revisi tahun 2017. Keterbatasan peneliti saat mau menampilkan video untuk mengenalkan kepada siswa itu juga kesusahan akirnya peneliti memanfaatkan yang ada dengan menampilkan ceritanya itu menggunakan laptop pribadi dengan antisipasi membentuk empat kelompok dengan lima siswa untuk memudahkan siswa dalam melihat cerita asal usul Dam Bagong. Setelah selesai melihat video peneliti memberikan buku teks kepada siswa untuk dibaca terlebih dahulu cerita mengenai asal usul Dam Bagong setelah itu siswa ditugasi menceritakan satu per satu di depan kelas mengenai poin yang terkandung didalamnya (Riyadi, 2017). Hasil wawancara pada tanggal 1 Juli 2019 di SDN 1 Ngatru Trenggalek terkait bahan ajar yang digunakan guru. Diperoleh informasi bahwa diperlukannya bahan ajar pendukung berbasis kearifan lokal Trenggalek dan ritual yang terkandung dalam ritual Nyadran Dam Bagong yang dapat menunjang kegiatan belajar siswa. Guru juga belum pernah membuat buku teks tentang cerita ritual Nyadran Dam Bagong ucap guru kelasnnya sendiri bilang mencari reverensi yang valid itu yang sudah karena harus ke dinas pariwisata dan pengurusan meminta data itu juga lumayan rumit. Peneliti tidak hanya membuat buku teks, tetapi juga membuat video yag didalamnnya terdapat crita asal usul dam bagong yang berbasis komputer dikarenakan keterbatasan kemampuan. Guru merasa kesulitan jika harus membuat media berupa buku teks serta video yang berbasis komputer. Padahal menurut guru, sekolah sudah menyediakan fasilitas, seperti komputer dan laptop, tetapi guru kurang memanfaatkan fasilitas tersebut tidak mau berpikir terlalu ribet, siswa hanya diberi tugas belajar di luar kelas dan memanfaatkan fasilitas yang ada di lingkugan sekolah saja (Oliver, 2013).

Manfaat peneliti membuat buku taks untuk siswa adalah untuk memudahkan siswa untuk mengenal sejarah ritual Nyadran Dam Bagong yang ada di Treggalek serta makna yang terkandug didalamnya (Bradshaw et al., 2020). Tidak hanya buku teks saja yang ditampilkan untuk siswa peneliti juga menampilkan sebuah penelitiaan tentang asal usul Dam Bagong yang peneliti dapatkan dari dinas pariwisata disini niat peneliti untuk memudahkan siswa mengenal tentang sejarah Dam Bagong serta asal usul berdirinya dam bagong serta ritual yang hanya dilakukan satu tahun sekali tepatnya di bulan Suro tanggalan jawa dan tradisi ini sudah menjadi tolak balak warga Trenggalek. Unsur yang terkandung di dalam tradisi ini hanya untuk memperingati perjuangan Adipati Minak Sopal. Selain itu, siswa juga dapat meningkatkan kemampuan berpikir tingkat tinggi (Edelweis \& Desa, 2018). Penggunaan video dan buku teks ini juga dapat meningkatkan aktivitas belajar siswa (Hasanah, 2016). Selain itu, mampu menciptakan keterlibatan siswa dalam kegiatan pembelajaran,(Widati, 2011). Selain itu, penggunaan buku teks juga dapat memberikan pengalaman yang bermakna kepada siswa (Azizah, 2018). Nilai-nilai ritual Nyadran Dam Bagong sebagai wujud pelestarian budaya lokal dan sumber belajar IPS SD. Muatan yang dikembangkan, meliputi (1) tradisi Nyadran Dam Bagong di kelurahan Ngatru, Trenggalek; (2) sejarah Dam Bagong; (3) asal usul Dam Bagong; (4) prepektif tradisi Nyadran bagi masyarakat; (5) makna simbolik Nyadran Dam Bagong untuk perjuangan Adipati Minak Sopal; (6) sebagai sumber belajar siswa kelas IV SDN 1 Ngatru Trenggalek.

Suatu ringkasan peristiwa adat dapat dijadikan sebagai sumber belajar untuk siswa sekolah dasar kelas IV, pembelajaran seperti hasil penelitian yang dilakukan oleh Dewi (2018) yang mengemukakan bahwa upacara adat adat di dusun Tunggul Arum desa Wonokarto kecamatan Turi, kabupaten Sleman masih melakukannya dari tahun ke tahun dan diberikan pengaruh tentang pendidikan baik formal maupun informal. Upacara adat yang dapat mempertebal nilai keimanan, membina rasa persatuan dan kebersamaan. Sejalan dengan penelitian Pada et al. (2018) kegiatan pembelajaran sejarah dengan 
memanfaatkan upacara ritual bersih desa dapat meningkatkan apresiasi siswa terhadap budaya lokal yang ada di Indonesia. Hasil data keefektifan dibuktikan dengan meningkatnya hasil belajar siswa dengan menggunakan buku teks untuk mengenalkan siswa tentang kebudayaan yang ada di Trenggalek, yaitu ritual Nyadran Dam Bagong.

Paparan data yang dijelaskan sebelumnya dapat disimpulkan menjadi empat hal, yaitu (1) muatan materi kearifan lokal yang ada di dalam buku masih berskala nasional dan belum mengembangkan kearifan lokal daerah sekitar siswa, (2) media yang digunakan untuk menyampaikan materi hanya sebatas pada buku cerita, (3) terdapat fasilitas teknologi yang menunjang untuk mengembangkan multimedia interaktif dengan adanya laptop agar lebih menarik, (4) buku teks tetang kearifan lokal budaya Trenggalek dan tentang sejarahnya, melibatkan siswa dalam kegiatan pembelajaran, dan didesain sesuai dengan kebutuhan siswa, yaitu buku teks dan video pembelajaran tentang kearifan lokal Trenggalek.

Aries, Soffya, Sudarmiatin, Kuswandi (2016) buku teks yang digunakan peneliti berbasis kearifan lokal kabupaten trenggalek yang dikembangkan didasarkan pada kebutuhan untuk mendukung kegiatan pembelajaran. Selain itu, buku teks dan video yang dikembangkan peneliti didapatkan dari referensi dari dinas pariwisata untuk memudahkan siswa dalam mengenalkan tentang sejarah da nasal usul dam bagong yang dilakukan setiap satu tahun sekali di kelurahan Ngatru Trenggalek dan yang dikembangkan dapat menciptakan pembelajaran yang bersifat kontekstual dan menarik pada siswa karena mengintegrasikan muatan materi IPS berbasis kearifan lokal ke dalam KD mata pelajaran lain.

Fokus penelitian (1) mendeskripsikan makna pelaksanaan ritual Nyadran Dam Bagong di kabupaten Trenggalek, (2) analisis nilai-nilai Nyadran Dam Bagong sebagai wujud pelestariaan budaya lokal Trenggalek, dan (3) analisis upacara tradisi Nyadran Dam Bagong yang dapat dijadikan sebagai sumber belajar IPS SD. Fokus penelitian yaitu makna tentang ritual Dam Bagong dan sumber belajar untuk siswa. Dalam penelitian ini, peneliti membuat buku teks untuk memudahkan siswa dalam mengenal sejarah tentang asal usul Dam Bagong di Trenggalek.

\section{METODE}

Model penelitian yang digunakan yaitu Pendekatan yang digunakan dalam penelitian ini adalah pendekatan etnografi. (Craswell 2012). Penelitian etnografi merupakan salah satu strategi penelitian kualitatif yang didalamnya peneliti menyelidiki suatu kelompok kebudayaan di lingkungan yang alamiah dalam periode waktu yang cukup lama dalam pengumpulan data utama, data observasi, dan data wawancara (Nurjanah, 2013). Alasan peneliti digunakannya pendekatan etnografi ini adalah sebagai deskripsi atas suatu kebudayaan untuk memahami suatu pandangan hidup dari sudut pandang pendidik asli Trenggalek menjelaskan bahwa dalam penelitian etnogarafi merupakan suatu metode penelitian ilmu social yang sangat dipercaya pada ketertutupan oleh para peneliti. (Edelweis \& Desa, 2018) Etnografi adalah suatu bentuk penelitian yang berfokus pada makna sosiologi melalui observasi lapangan tertutup dari fenomena sosiokultural.

Penelitian ini mengguanakan model pendekatan etnografi menurut Yuliningsih et al. (2019) pertimbangan penggunaan dan pendekatan Etnografi tradisi ritual dam bagong diadakan setiap bulan suro dan selalu menumbalkan kepala kerbau. Sebelum melakukan ritual selalu pergi ke makma yang didekat dam bagong terdapat dua makam merupakan makam Minak Sopal dan Ibu Dewi Roro Amiswati. Makam yang di sebelah kanan merupakan makam dari Minak Sopal, sedangkan makam di sebelah kiri adalah makam Dewi Roro Amiswati dengan nuansa religi dan tradisi budaya yang masih kental. Pengembangan buku teks diawali dengan studi pendahuluan yang dilaksanakan di SDN 1 Ngatru kabupaten Trenggalek pada tanggal 1 Juli 2019. Subjek uji lapangan yaitu seluruh siswa kelas IV SDN 1 Ngatru terdiri dari 25 siswa dan peneliti melakukan uji kelompok kecil diikuti oleh lima siswa yang berkategori rendah, sedang, dan tinggi.

Sumber data yang digunakan yaitu sumber data (1) sumber data lisan atau wawancara, (2) sumber data fisik yaitu berupa buku mengenai sejarah Dam Bagong yang diberikan oleh dinas pariwisata untuk penguat judul tesis, (3) video bukti prosesi dari awal sampai akir untuk bukti lapangan, dan (4) membuat buku teks untuk memudahkan siswa dalam mengenal sejarah Dam Bagong.

Terdapat lima langkah pembuatan prosedur buku teks yang diperlukan dalam model (Yama et al., 2018), meliputi (1) analisis yang akan dikembangkan; (2) desain tampilan; (3) pengembangan buku teks; (4) penerapan produk yang dikembangkan; (5) peninjauan ulang dari hasil produk yang diterapkan dan video yang akan digunakan untuk memudahkan siswa mengenal kearifan lokal kabupaten Trenggalek.

\section{HASIL}

Hasil penelitian yang didapatkan di lapangan adalah data-data penelitian ini tentang sejarah nyadaran dam bagong untuk mengenalkan siswa tentang sejarah serta tradisi yang dilakukan dibulan suro. Hasil penelitian yang telah diperoleh akan dideskripsikan secara rinci. Bruno (2019) sejarah Trenggalek menjadi bahan acuan dalam pembuatan penelitian selain pembahasan mengenai tradisi Nyadran peneliti membuat sebuah buku teks ini untuk memudahkan siswa memahami sejarah dan asal usul Dam Bagong. Didalam buku teks ini, terdapat gambar dan penjabaran tentang sejarah Dam Bagong. Gambar yang ditampilkan dapat berupa foto, video, sedangkan tulisan dapat berupa kata, kalimat maupun paragraf. Keterpaduan teks, gambar, dan video yang menyeluruh dan sistematis dapat mendorong antusias belajar siswa dari pada menggunakan buku teks saja saat ditampilkan sebuah video tentang sejarah dam bagong siswa sangat memperhatikan itu dan mendengarkan cerita-cerita tersebut dengan cermat (Sufia et al., 2016). 
Buku teks yang disajikan peneliti untuk memudahkan siswa mengenal tentang sejarah Dam Bagong dan dilengkapi dengan gambar yang mendukung. Didalam hasil penelitian ada paparan tentang pelaksanaan ritual Nyadran Dam Bagong didalam pelaksanaan ritual Nyadran Dam Bagong dilakukan pada bulan suro dan dilakukan di sebelah makam Adipati Minak Sopal kelurahan Ngatru. Dulunya mayoritas warga Trenggalek adalah petani, maka Adipati Minak Sopal berkeinginan untuk membuat sebuah tanggul air untuk mengairi sawah warga Trenggalek (Darisma, Midhio, Prasetyo, 2018). Akan tetapi, Adipati Minak Sopal selalu gagal saat pembuatan aliran Dam, lalu Adipati Minak sopal bertanya kepada ayahnya mengenai aliran Dam yang dibuatnya selalu gagal. Setelah itu, ayah Adipati Minak Sopal yaitu Minak Seraba memberi petunjuk kepada Adipati Minak Sopal agar Dam yang dibuatnya cepat selesai carilah tumbal gajah putih. Gajah putih tersebut hanya dimiliki oleh seorang janda dari Ponorogo bernama Mbok Rondo Krandon.

Pada saat itu adipati dan pengawalnnya berangkat ke Ponorogo untuk meminjam gajah puih milik Mbok Rondo Krandron. Adipati Minak Sopal hanya bilang kepada Mbok Rondo Krandon gajahnnya hanya dipinjam sebentar untuk menginjak tanah yang akan dibuatnnya aliran Dam Bagong untuk warga Trenggalek (Bruno, 2019). Pada akhirnnya, gajah putih yang dibutuhkan Adipati Minak Sopal berhasil dibawanya ke Trenggalek untuk disembelih dagingnya dibagi-bagikan kepada warga Trenggalek dan kepalanya dilemparkan ke dalam Dam (Sakariah, 2018). Jadi, sekarang tradisi tersebut sangatlah dipercaya oleh warga Trenggalek. Tradisi Nyadran merupakan ritual simbolik makna dan tradisi. Nyadran merupakan salah satu bagian dari adat istiadat yang terdapat di masyarakat, yaitu bentuk suatu perayaan yang didalamnya terdapat nilai budaya dan sekaligus kesakralan yang dapat memberikan inspirasi bagi kekayaan budaya daerah dan juga budaya nasional. Tradisi tersebut memberikan pelajaran kepada manusia bahwa manusia berbudaya itu harus mampu mengemban amanah atas kelestariaan alam beserta isinya.

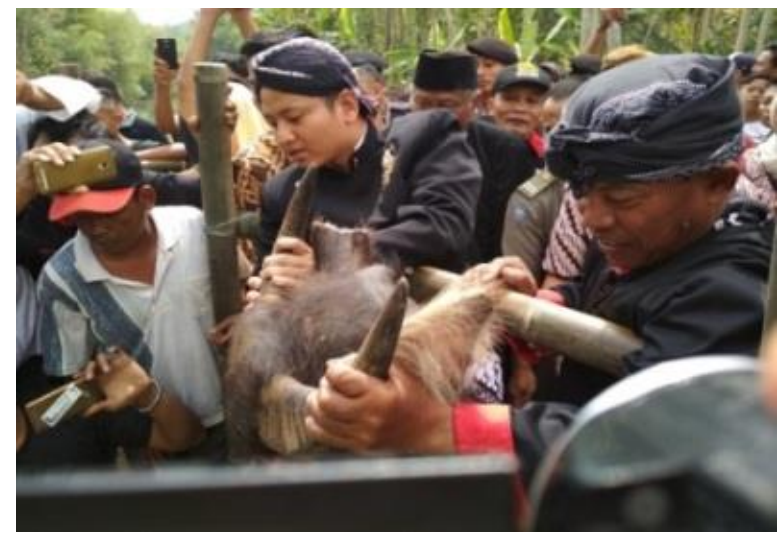

Gambar 1. Para warga trenggalek dan bapak bupati trenggalek sedang melakukan pelemparan kepala kerbau ke dalam Dam Bagong (sumber: Siti Zullaikah 13/09/2019)

(1) penyembelihan kepala kerbau, (2) bersesaji yang biasannya dilakukan oleh dalang ketika ruwatan, (3) berdoa di sebelah makam adipati minak sopal, (4) prosesi yang dilakukan dibulan suro yang diperlukan adalah sesaji dan $1-2$ kerbau, tetapi yang dilerungkan ke dalam dam adalah kepala kerbau, kulit, dan kaki, (5) makan bersama bersama masyarakat Trenggalek, dan (6) ruwatan wayang kulit dan jaranan di area Adipati Minak Sopal. Sebelum melakukan pelemparan kepala kerbau bapak bupati nur arifin melakukan ziarah kemakam adipati minak sopal dan memohon ijin untuk melakukan pelemparan kepala kerbau ke dalam Dam sebagai wujud syukur kepada Allah karena berkat perjuangan Adipati Minak Sopal untuk pembangunan Dam Bagong ini perairan yang ada di Trenggalek tidak kekeringan lagi.

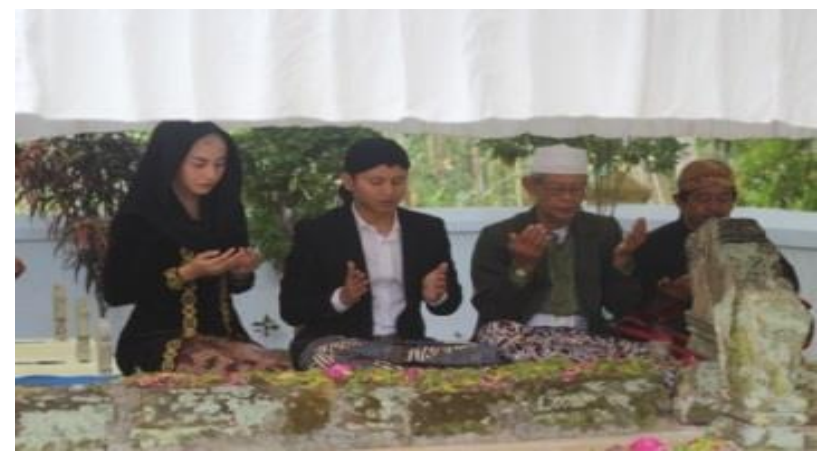

Gambar 2. Bapak Nurarifin dan Istrinya Berdoa Dimakam Adipati Minak Sopal (Sumber: Siti Zullaikah 13/09/2019) 
Salah satu wisata budaya yang masih dilestarikan hingga saat ini di kabupaten Trenggalek yaitu bersih Dam Bagong yang tepatnya terletak di kelurahan Ngantru kecamatan Trenggalek kabupaten Trenggalek atau warga sekitar menyebutnya dengan istilah Nyadran Dam Bagong. Tradisi Nyadran merupakan ritual simbolik makna dan tradisi. Nyadran merupakan salah satu bagian dari adat istiadat yang terdapat di masyarakat, yaitu bentuk suatu perayaan yang didalamnya terdapat nilai budaya dan sekaligus kesakralan yang dapat memberikan inspirasi bagi kekayaan budaya daerah dan juga budaya nasional. Tradisi tersebut memberikan pelajaran kepada manusia bahwa manusia berbudaya itu harus mampu mengemban amanah atas kelestariaan alam beserta isinya. Selain larung kepala kerbau, sejumlah prosesi lain juga digelar di kawasan makam Menak Sopal, salah satunya pagelaran wayang ruwat, selamatan, dan doa bersama. Acara yang paling ditunggu-tunggu ribuan masyarakat yang hadir adalah prosesi pelemparan kepala kerbau serta aneka tulang dan kulit kerbau ke dalam Dam Bagong. Sejumlah warga yang telah menunggu di dasar dam langsung menceburkan diri ke dalam dam untuk mencari potongan kepala kerbau maupun kulit dan tulangnya.

Salah seorang peserta akhirnya berhasil mendapatkan kepala kerbau setelah menyelam di kubangan Dam Bagong. Proses rebutan inilah yang paling menarik perhatian warga yang menonton. Lebih lanjut, Naim menjelaskan, kepala kerbau yang di lempar tersebut merupakan simbol dari pengorbanan, sekaligus pengganti kepala gajah putih yang konon dahulu digunakan untuk prasyarat proses pembangunan dam. Dalam legenda yang diceritakan secara turun-temurun, saat membangun waduk kecil tersebut, Menak sopal selalu mengalami kegagalan. Atas saran dari gurunya ia pun di minta untuk mengorbankan sekor gajah putih dan gajah putih itu yang dipinjah dari mbok rondo kandron berhunung perubahan jaman begitu cepat mencari gajah putih itu susah sekarang diganti dengan kebo bule kerbau yang berwarna coklat kehitampan dan yang berbadan besar untuk mengganti gajah putih tersebut.

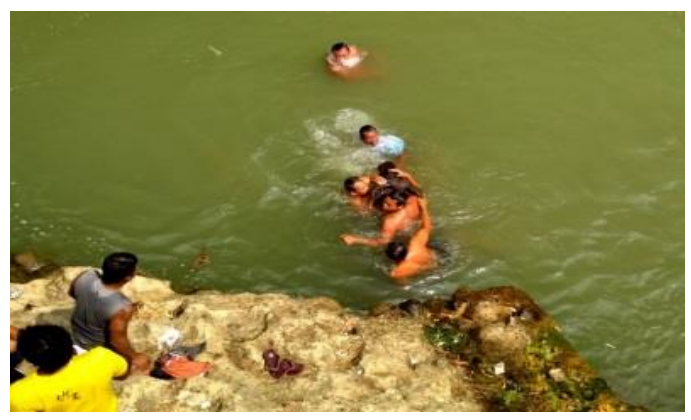

Gambar 3. Warga beramai-ramai merebutkan kepala kerbau yang dilemparkan kedalam dam bagong (sumber: Siti Zullaikah 13/09/2019)

Tradisi ini merupakan warisan nenek moyang yang tetap diperingati sampai sekarang ini. Berdasarkan hasil wawancara dalam peringatan upacara tradisi nyadran di Dam Bagong Kelurahan Ngantru masyarakat harus bergotong-royong dalam mempersiapkan segala sesuatu yang diperlukan saat pelaksanaan upacara tradisi nyadran tersebut. Karena dalam pelaksanaan upacara tradisi nyadran tersebut banyak sekali perlengkapan yang harus dipersiapkan. Misalnya saja, sebelum pelaksanaan upacara tersebut masyarakat bergotong-royong membersihkan tempat atau makam yang akan digunakan untuk memperingati nyadran di Dam Bagong serta membuat panggung dan mendirikan terop. Masyarakatlah yang mempersiapkan perlengkapan yang akan dijadikan sebagai perlengkapan nyadran dan ruwatan saat pelaksanaan upacara nyadran di Dam Bagong Kelurahan Ngantru.

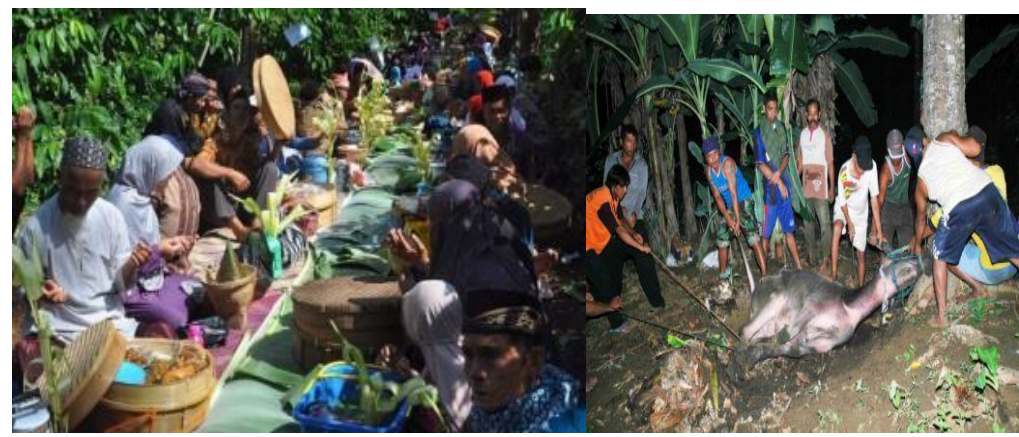

Gambar 4. Bahan-bahan yang diperlukan saat prosesi ritual Nyadran Dam Bagong yaitu mule dan kerbau serta bunga untuk nyekar didalam makam Adipati Minak Sopal (sumber: siti zullaikah 13/09/2019) 
Sebagai sumber belajar IPS pada jenjang SD merupakan suatu bahan kajian yang terpadu merupakan penyerderhanaan keterampilan sejarah dan geografi melalui mata pelajaran IPS siswa mengenal tentang sejarah yang ada disekiatr kita contohnya sejarah tentang tradisi nyadaran dam bagong, peserta didik diarahkan untuk menjadi warga dunia yang cinta damai proses belajar IPS berusaha menanamkan kepada siswa tentang aspek koknitif, afektif, dan psikomotorik pada siswa. Tujuannya adalah membina warga negara yang baik dan mempunyai pengetahuan dan keterampilan serta kepedulian sosial berguna bagi dirinya sendiri serta bagi masyarakat dan negara sekitar kita. Terkait dengan hal tersebut adannya upacara tradisi nyadaran dam bagong mengandung nilai-nilai yang dapat dimanfaatkan dalam pembelajaran IPS di SD. Nilai-nilai dari upacara-upacara tradisi Nyadran Dam Bagong yang dapat diterapkan dalam pembelajaran IPS meliputi nilai religius, nilai tanggung jawab, nilai musyawarah, nilai gotongroyong dan nilai kedisiplinan. Nilai-nilai tersebut dapat diterapkan sebagai pembelajaran IPS SD di kelas IV, yang terkait dengan aspek afektif.

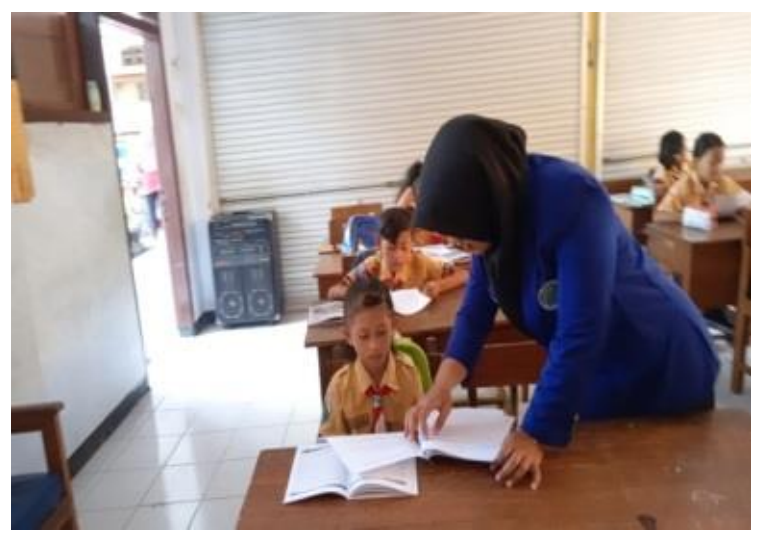

Gambar 5. Peneliti melakukan penelitian di SDN 1 Ngatru untuk mengenalkan kepada siswa tentang sejarah Dam Bagong kepada siswa (sumber data: siti zullaikah 18/11/2019)

Nilai religius bersifat mutlak dan abadi, serta bersumber pada keyakinan merupakan hidayah dari Tuhan Yang Maha Esa merupakan kekuatan sejati tempat manusia memohon dan bersyukur atas rahmat yang diberikan. Manusia sadar dan yakin bahwa Tuhan Yang Maha Esa memiliki kekuasaan atas segala yang terjadi di dunia juga di akherat. Oleh karena itu, manusia meminta izin dari Tuhan-nya agar mendapatkan jalan untuk mencapai keselamatan dan kesejahteraan. Nilai religius harusnya selalu mengiringi setiap kegiatan masyarakat, termasuk dalam hal pendidikan. Hubungan yang saling berkaitan antara ilmu pengetahuan dan religiusitas. Ada istilah yang menyatakan bahwa ilmu tanpa iman akan pincang, iman tanpa ilmu akan sangat besar. Ilmu pengetahuan akan berkembang dengan baik dan tidak disalahgunakan jika didasari religiusitas. Begitu juga ilmu pengetahuan yang membantu manusia, sangat meningkat keagungan, Tuhan begitu religiusitas akan semakin kuat.

Tanggung jawab adalah tindakan manusia yang akan diwujudkan kesadaran. Dimana manusia merasa bertanggung jawab atas perbuatan yang dilakukan tersebut dalam kegiatan pembelajaran seharusnnya disertai tanggung jawab yang baik dari guru maupun dari siswa. Sudah menjadi tugas guru sebagai pelajar dan pendidik, sedangkan siswa berkewajiban untuk belajar dan menerima ilmu. Bahkan siswa dan guru terjadi proses pembelajaran dan mengembangkan metode-metode yang baik.

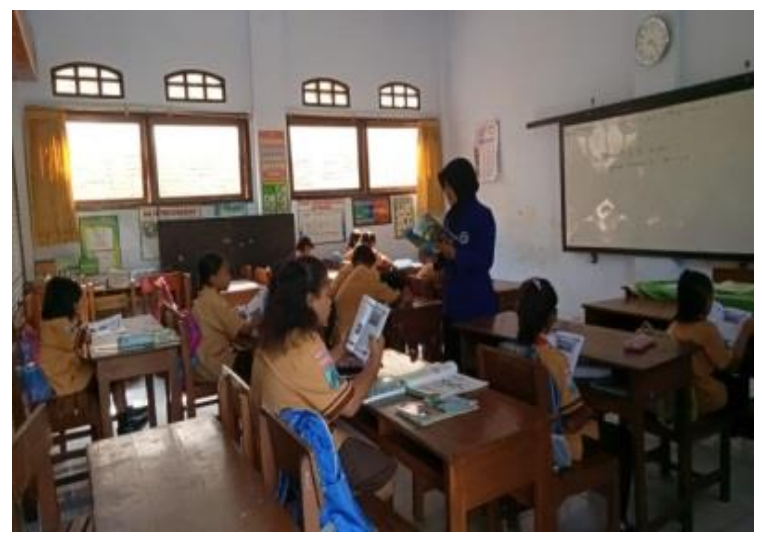

Gambar 6. Siswa dan peneliti membaca buku teks tentang ritual nyadran dam bagong dan mengenalkan kepada siswa tentang sejarah dam bagong kepada siswa (sumber data: siti zullaikah 18/11/2019) 
Upacara tradisi bersih Dam Bagong jika dilihat dari kondisi sosial budayanya, masyarakat kelurahan Ngantru masih menganut nilai-nilai budaya jawa yang menjunjung tinggi kedamaian dan bergotong royong. Dalam hal ini dapat dibuktikan bahwasannya sebagian besar masyarakat mengadakan kerja bakti setiap hari Minggu. Jiwa dan semangat gotong royong ini diartikan sebagai perasaan real terhadap sesama masyarakat Kelurahan Ngantru (Makhmudah, 2017). Dalam hal ini, kebutuhan umum nilainya lebih tinggi dibandingkan kebutuhan pribadi sehingga kerja bakti untuk umum nilainya sangat terpuji. Seperti halnya dengan upacara Bersih Dam Bagong bahwasannya bergotong royong merupakan simbol kebersamaan yang dilakukan masyarakat Ngantru dalam mempersiapkan upacara tersebut.

\section{PEMBAHASAN}

Pelaksanaan ritual Dam Bagong adalah suatu ringkasan kegiatan yang terkait dengan aturan-aturan tertentu menurut adat yang ada dalam suatu kelompok masyarakat. Upacara ritual Nyadran Dam Bagong ini untuk mendekatkan manusia dengan alam lingkungan, manusia dengan sesamanya serta manusia dengan Tuhan. Upacara ritual Nyadran Dam Bagong adalah bentuk apresiasi masyarakat yang berhubungan dengan unsul emosi, religius, dan keagamaan. Berbagai macaram upacara Nyadran Dam Bagong terdapat dalam masyarakat jawa merupakan cerminan bahwa semua perencanaan tindakan dan perbuatan yang telah diatur oleh tata nilai dan norma.

Upacara ritual Nyadran Dam Bagong yang terdapat dalam masyarakat jawa merupakan cerminan bahwa semua perencanaan tindakan dan perbuatan telah diatur oleh tata nilai dan norma. Nilai-nilai yang terkandung dalam ritual Nyadran Dam Bagong ini berkaitan dengan kepercayaan akan kekuatan di luar manusia dengan tujuan demi tercapainya keselamatan maupun keinginan serta harapan-harapan warga Trenggalek. Upacara Nyadran yang dilakukan di bulan Suro ini bertujuan untuk mengucap syukur kepada Adipati Minak Sopal atas perjuangannya selama ini untuk Trenggalek, yakni membuatkan perairan warga agar Trenggalek menjadi maju. Tradisi inipun sudah menjadi tolak balak dan kepercayaan warga Trenggalek (Su'udiah, Degeng, Kuswandi, 2016).

Nilai dalam upacara tradisi Nyadran Dam Bagong merupakan suatu penghargaan terhadap sesuatu hal yang dapat menjadi dasar seseorang dalam bertingkah laku di dalam masyarakat. Nilai dalam upacara tradisi Nyadran Dam Bagong adalah suatu yang berharga dan berkualitas serta dijunjung tinggi dan mengandung harapan atau sesuatu yang diinginkan manusia. Oleh karena itu, nilai bersifat normatif dan merupakan keharusan untuk mewujudkan dalam sikap dan tingkah laku. Menurut Zulia \& Yanuwiadi (2015) nilai adalah suatu yang dianggap positif, dihargai, dipelihara, diagungkan dan dihormati membuat orang gembira dan bersyukur. Oleh karena itu, tingkah laku manusia, pola pikir, dan kebiasaan yang ada dalam masyarakat merupakan gambaran dari nilai yang diyakini kebenarannya. Berdasarkan penelitian yang terdapat banyak sekali nilai positif yang terkandung dalam uapacara tradisi Nyadran Dam Bagong yang dilakukan di bulan Suro. Dari nilai-nilai tersebut dapat dirangkum menjadi nilai religius, tanggung jawab, musyawarah, partisipasi aktif, dan gotong royong.

\section{SIMPULAN}

Kesimpulan yang dapat diambil tentang prosesi ritual Nyadaran Dam Bagong, yaitu (1) upacara tradisi Nyadran Dam Bagong adalah tradisi yang diselenggarakan setiap satu tahun sekali oleh masyarakat Trenggalek, kelurahan Ngatru, kabupaten Trenggalek, Provinsi Jawa Timur, (2) tradisi ini merupakan prosesi upacara adat menggunakan tumbal kepala kerbau yang dilemparkan ke dalam Dam yang dilaksanakan setiap tanggal 1 Muharam (penanggalan Hijriyah) atau 1 Suro (penanggalan Jawa), (3) nilai-nilai dalam upacara tradisi Nyadran Dam Bagong dapat diintegrasikan pada pembelajaran IPS di SD yang mengkhususkan pada aspek afektif. Nilai-nilai tersebut akan terlihat pada kegiatan pembelajaran, baik pada perilaku, sikap maupun kerjasama siswa dalam proses pembelajaran. Selain aspek afektif, pertemuan upacara tradisi Nyadran Dam Bagong juga dapat diintegrasikan pada aspek kognitif pembelajaran IPS di SD. Selain itu, upacara tradisi Nyadran Dam Bagong dapat dimasukkan ke dalam materi pembelajaran IPS kelas IV SD.

Kesadaran masyarakat Trenggalek dalam perayaan upacara adat bersih Dam Bagong dianggap aktivitas kebudayaan itu adalah benar. Dalam kegiatan tersebut, tradisi yang ada dalam suatu masyarakat sebagai budaya yang baik dan kesadaran masyarakat harus tetap dikembangkan karena berhubungan dengan ruang dan waktu pada zaman dahulu. Upacara tradisi bersih Dam Bagong adalah sebuah tradisi yang biasanya dilakukan oleh masyarakat Ngantru, Trenggalek. Tradisi ini biasanya dilakukan di Dam Bagong tepatnya di sungai besar. Upacara ini merupakan kegiatan yang sangat baik dapat menyatukan elemen masyarakat dengan kegiatan-kegiatan yang positif berisi unsur keimanan dan kepercayaan. 


\section{DAFTAR RUJUKAN}

Riyadi. A. (2017). Kearifan Lokal Tradisi Nyadran Lintas Agama di Desa Kayen-Juwangi Kabupaten Boyolali. Jurnal SMART (Studi Masyarakat, Religi, dan Tradisi) 3(2), 139-154.

Aries, S., Sudarmiatin., \& Kuswandi, D. (2016). Peranan Multimedia Interaktif Pembelajaran IPS Siswa Kelas IV Sekolah Dasar. Jurnal Pendidikan, 1(2), 1-8.

Azizah, S. N. (2018). International Mobility Based on Women Labour: Study of Changes in Socio-Economic-Cultural Family Former migrant worker Jakatawa Bulaksari In the village, District Bantarsari, Cilacap Seen From the Perspective of Islamic Economic Theory. Ijtimā'iyya: Journal of Muslim Society Research, 3(1), 129-149. https://doi.org/10.24090/ijtimaiyya.v3i1.1744

Bradshaw, M. J., Bhattacharyya, S., Venna, N., \& Cahill, J. F. (2020). Neurologic Manifestations of Systemic Rheumatologic Diseases. In Current Clinical Neurology (pp. 321-342). https://doi.org/10.1007/978-3-030-24436-1_17

Darisma, N. S., Midhio, I. W., \& Prasetyo, T. B. (2018). Aktualisasi Nilai-Nilai Tradisi Nyadran sebagai Kearifan Lokal Dalam Membangun Budaya Damai di Giyanti, Wonosobo. Jurnal Damai dan Resolusi Konflik, 4(1), 21-44.

Dewi, I. N., Poedjiastoeti, S., \& Prahani, B. K. (2017). ElSII Learning Model Based Local Wisdom to Improve Students' Problem Solving Skills and Scientific Communication. International Journal of Education and Research, 5(1), $107-118$.

Dewi, T. K. S. (2018). Panji Tradition in the Jaranan Jor and Wayang Timplong Performance Arts in East Java. ISLLAC : Journal of Intensive Studies on Language, Literature, Art, and Culture, 2(2), 13-20. https://doi.org/10.17977/um006v2i22018p013

Hasanah, H. (2016). Implikasi Psiko-Sosio-Religius Tradisi Nyadran Warga Kedung Ombo Zaman Orde Baru (Tinjauan Filsafat Sejarah Pragmatis). Wahana Akademika, 3, 1-20.

Iswanto, A. (2018). Kajian Teologi Penciptaan Alam dan Manusia Nurhata Revitalisasi Kearifan Lokal Naskah-naskah Primbon Koleksi Masyarakat Indramayu. Jurnal Manassa, 8(2).

Makhmudah, S. (2017). Mensinergikan Nilai-Nilai Keagamaan dengan Kearifan Lokal sebagai Upaya Mewujudkan Masyarakat Madani (Studi Kasus Komunitas Keagamaan Kejawen di Desa Bajulan Kecamatan Loceret Kabupaten Nganjuk). Jurnal Konseling dan Pendidikan, 5(1), 11. https://doi.org/10.29210/113600

Nurjanah, T. I. (2013). Tradisi Nyadran sebagai Wujud Pelestarian Nilai Gotong-Royong Para Petani di Dam Bagong Kelurahan Ngantru Kecamatan Trenggalek Kabupaten Trenggalek. Skripsi tidak diterbitkan. Universitas Negeri Malang, Malang.

Rufaidah, D., \& Sayekti, O. M. (2018). Struktur Wacana Dalam Ritual Nyadran Agung di Kabupaten Kulon Progo. Widyaparwa, 46(2), 168-178.

Sakariah, D. S. (2018). Pemanfaatan Seni Kertas Lipat sebagai Bentuk Antisipasi Demensia pada Masyarakat Lanjut Usia di Desa Sekarjalak. Jurnal Harmoni, 2(1), 26-30.

Su'udiah, F., Degeng, I. N. S., \& Kuswandi, D. (2016). Pengembangan Buku Teks Tematik Berbasis Kontekstual. Jurnal Pendidikan: Teori, Penelitian, dan Pengembangan, 1(9), 1744-1748.

Sufia, R., Sumarmi, \& Amirudin, A. (2016). Kearifan Lokal Dalam Melestarikan Lingkungan Hidup (Studi Kasus Masyarakat Adat Desa Kemiren Kecamatan Glagah Kabupaten Banyuwangi). Jurnal Pendidikan: Teori, Penelitian, dan Pengembangan, 1(4), 726-731.

Widati, S. (2011). Tradisi Sedekah Laut di Wonokerto Kabupaten Pekalongan: Kajian Perubahan Bentuk dan Fungsi. Jurnal Penelitian Pendidikan, 1(2), 142-148.

Prasetya, A. Y. W. N., Kuswandi, D., \& Akbar, S. (2018). Multimedia Interaktif pada Pembelajaran Tematik untuk Kelas IV Sekolah Dasar. Jurnal Pendidikan: Teori, Penelitian, dan Pengembangan, 3(11), 1423-1427.

Yuliningsih, Y., Saddhono, K., \& Setiawan, B. (2019). Internalizing the Local Wisdom Value of Nyadran Tradition to Students through Audio Visual Media. Proceedings of the $1^{\text {st }}$ Seminar and Workshop on Research Design, for Education, Social Science, Arts, and Humanities, SEWORD FRESSH 2019, April 27 2019, Surakarta, Central Java, Indonesia https://doi.org/10.4108/eai.27-4-2019.2286937

Zulia, Z., \& Yanuwiadi, B. (2015). The Natural and Cultural Resources for Ecotourism Development in Trenggalek Regency, East Java. Journal of Indonesian Tourism and Development Studies, 3(2), 45-52. https://doi.org/10.21776/ub.jitode.2015.003.02.02 